\title{
PENENTUAN ALTERNATIF LOKASI TEMPAT PEMBUANGAN AKHIR (TPA) DI KOTA BANDAR LAMPUNG MENGGUNAKAN SISTEM INFORMASI GEOGRAFIS
}

\author{
Ongky Anggara ${ }^{*}$, Indri Nurlisa Febrina ${ }^{2}$, Agel Vidian Krama ${ }^{3}$, Dudung Muhally Hakim ${ }^{4}$ \\ 1,2,3Teknik Geomatika, Institut Teknologi Sumatera, Lampung, Indonesia \\ ${ }^{4}$ Teknik Geodesi dan Geomatika, Institut Teknologi Bandung, Bandung, Indonesia \\ *Email Koresponden: ongky.anggara@staff.itera.ac.id
}

Diterima: 27-04-2021, Revisi: 16-05-2021, Disetujui: 08-06-2021

C)2021 Program Studi Pendidikan Geografi, FISE, Universitas Hamzanwadi

\begin{abstract}
Abstrak Volume sampah yang terus meningkat dan kapasitas Tempat Pembuangan Akhir (TPA) Sampah di Kota Bandar Lampung yang semakin terbatas harus menjadi perhatian serius. Termasuk dengan merencanakan lokasi TPA yang baru, agar permasalahan sampah mampu dikurangi. Hal ini dilakukan mengingat di Kota Bandar Lampung hanya terdapat satu TPA yaitu TPA Bakung yang berlokasi di Kelurahan Bakung Kecamatan Teluk Betung Timur. Penelitian ini bertujuan untuk menentukan lokasi alternatif Tempat Pembuangan Akhir (TPA) dengan menggunakan sistem pengelolaan berbasis sanitary landfill. Penentuan alternatif lahan Tempat Pembuangan Akhir (TPA) sampah dalam penelitian ini menggunakan standar SNI 033241-1994. Penentuan lokasi alternatif menggunakan analisis Sistem Informasi Geografis dengan metode skoring dan overlay melalui 3 proses tahapan analisis yaitu: 1) tahap regional; 2) tahap penyisih; 3) tahap penetap. Berdasarkan hasil analisis rekomendasi lokasi alternatif TPA Kota Bandar Lampung terdapat pada wilayah Kecamatan Teluk Betung Barat dan kecamatan kemiling dengan total luas sebesar 477.48 Hektar dengan luasan wilayah data yang telah divalidasi sebesar 42.16 Hektar, validasi yang dilakukan ditinjau dari aksesibiltas jalan menuju lokasi yang sangat baik, kemiringan lereng di bawah $20 \%$ serta luasan lahan yang cukup luas menunjukan lokasi tersebut sesuai untuk alternatif Tempat Pembuangan Akhir (TPA) Sampah di Kota Bandar Lampung.
\end{abstract}

Kata kunci: Tempat Pembuangan Aakhir, alternatif lokasi, Sistem Informasi Geografis

\begin{abstract}
The increasing volume of waste and the increasingly limited capacity of the Final Disposal Site (FDS) in Bandar Lampung City must be a serious concern. This includes planning a new FDS location, so that the waste problem can be reduced. This was done considering that in Bandar Lampung City there is only one FDS, namely Bakung FDS which is located in Bakung Village, Teluk. Betung Timur District. This study aims to determine alternative locations for Final Disposal Sites (TPA) using a sanitary landfill-based management system. Determination of alternative land for Final Disposal Site (FDS) for waste in this study uses the SNI standard 03-3241-1994. Determination of alternative locations using Geographic Information System analysis with scoring and overlay methods through 3 stages of analysis process, namely: 1) regional stage; 2) the allowance stage; 3) settling stage. Based on the results of the analysis of recommendations for alternative locations for the Bandar Lampung City TPA, it is found in the Teluk. Betung Barat District and Kemiling District with a total area of 477.48 hectares with a validated data area of 42.16 hectares. The slope of the slope is below $20 \%$ and the land area is quite large, indicating that the location is suitable for alternative FDS in Bandar Lampung City.
\end{abstract}

Keywords: Final Disposal Site, alternative location Geographic Information System

\section{PENDAHULUAN}

Sampah telah menjadi permasalahan nasional sehingga pengelolaannya perlu dilakukan secara komprehensif dan terpadu dari hulu ke hilir agar memberikan manfaat secara ekonomi, kesehatan masyarakat, aman bagi lingkungan, serta dapat mengubah pola perilaku masyarakat untuk menumbuhkan rasa peduli terhadap lingkungan (Iriani, 2014). Permasalahan sampah di Indonesia merupakan salah satu masalah klasik yang hingga saat ini masih belum ditemukan solusinya secara 
komprehensif (Akbar, 2016). Tingginya jumlah penduduk dan keragaman aktivitas di kota-kota besar di Indonesia mengakibatkan munculnya berbagai persoalan dalam pelayanan prasarana perkotaan antara lain masalah sampah (Manik, 2003). Meningkatnya volume sampah tentunya juga beriringan dengan semakin bertambahnya jumlah penduduk (Mahyudin, 2017). Tidak dapat dipungkiri bahwa keberadaan Tempat Pembuangan Akhir (TPA) sampah pada suatu wilayah akan meningkatkan bahaya dan risiko pencemaran terhadap udara, air tanah, air permukaan, bau dan berkurangnya estetika lingkungan akibat adanya gas maupun air lindi (Kasam, 2011). Permasalahan sampah akan berdampak luas jika tidak dikelola dengan baik terutama akan menimbulkan dampak negatif terhadap permasalahan lingkungan. Selain dapat menimbulkan pencemaran lingkungan, sampah juga dapat memberikan pengaruh secara langsung terhadap kesehatan, kenyamanan keamanan/keselamatan hidup. Jumlah penduduk yang semakin pesat, perubahan pola konsumsi, dan gaya hidup masyarakat mengakibatkan produksi sampah terus meningkat menjadi suatu masalah yang berkembang di berbagai kawasan di dunia terutama di kota-kota besar termasuk di Indonesia. Adanya peningkatan kuantitas sampah memerlukan upaya serius untuk melakukan perbaikan dan pengembangan dalam sektor manajemen pengelolaan sampah untuk mengurangi dari dampak yang ditimbulkan (Chandra, 2006).

Tempat Pemrosesan Akhir dengan model sanitary landfill merupakan salah satu solusi yang tepat untuk mengatasi permasalahan persampahan di Indonesia (Apritama et al., 2016). Pengelolaan sampah dapat dilakukan dengan pengkomposan, pembakaran (thermal treatment), dan pembuangan di Tempat Pembuangan Akhir sampah (TPA) (open dumping) (Rahman \& Al-Muyeed, 2010). Namun demikian, di Indonesia pengolahan sampah sebagian besar hanya menggunakan metode open dumping karena prosesnya yang mudah dan murah (Hendra, 2016). Dalam rantai sistem manajemen sampah dikenal adanya Tempat Pembuangan Akhir (TPA). Berdasarkan Peraturan Daerah Provinsi Lampung Nomor 1 Tahun 2010 Tentang Rencana Tata Ruang Wilayah (RTRW) Provinsi Lampung (2009-2029), TPA sampah harus mengikuti pedoman pada studi AMDAL yang telah dibuat dan disepakati oleh instansi yang berwenang/terkait. Pengelolaan sampah dilakukan dengan sistem sanitary landfill sesuai ketentuan peraturan yang berlaku dalam pengelolaan lingkungan TPA sampah (Chandra, 2006). Dengan terbitnya Undang-undang Nomor 18 tahun 2008 tentang Pengelolaan Sampah yang menegaskan bahwa penanganan sampah di tempat pengolahan akhir dengan sistem pembuangan terbuka (open dumping) tidak diperbolehkan lagi (Pirngadi, 2013).

Bandar Lampung hanya memiliki satu lokasi Tempat Pembuangan Akhir (TPA) Sampah, yaitu TPA Bakung yang terletak di Kelurahan Bakung Kecamatan Teluk Betung Barat, dengan luas area sekitar 18 hektar (Sari, 2014). Berdasarkan standar buangan sampah perkapita 3,25/liter/orang/hari, maka total produksi sampah yang dihasilkan di Kota Bandar Lampung adalah lebih kurang 1.180 ton/hari dengan jumlah sampah terangkut oleh Dinas Kebersihan dan Pertamanan Kota Bandar Lampung sekitar $700 \mathrm{~m} 3 /$ hari (560 ton/hari) menggunakan 15 armada truk, dibuang ke Tempat Pembuangan Akhir (TPA) Bakung dengan menggunakan teknologi open dumping sejak tahun 1998, sedangkan sebelumnya menggunakan sistem sanitary landfill (Kesuma, 2011). Peningkatan jumlah timbulan sampah di Kota Bandar Lampung sendiri setiap harinya mencapai 750-800 ton/hari atau sekitar 292.000 ton/tahun dengan kepadatan penduduk yang paling besar pada tahun 2015 yakni 20.709 jiwa $/ \mathrm{km}^{2}$ (Phelia \& Damanhuri, 2019). Sistem pengolahan sampah TPA Bakung menggunakan sistem pembuangan terbuka (open dumping) yang sampai saat ini sistem pengolahan yang dilakukan dapat dikatakan belum baik karena belum sesuai dengan kriteria dan ketentuan yang berlaku. Penetapan Lokasi TPA pada dasarnya juga untuk kepentingan masyarakat dalam upaya menangulangi sampah kota (Fauzi, 2016). Penentuan TPA sampah juga harus mengikuti persyaratan dan ketentuan ketentuan yang telah ditetapkan pemerintah. Kriteria-kriteria penentuan lokasi TPA hendaknya dapat meminimalisir dampak kerusakan dan pencemaran lingkungan di sekitar lokasi TPA karena semuanya ditetapkan memperhatikan banyak aspek lingkungan, kesehatan, dan kebersihan, seperti kondisi geologis, mata air, lokasi pemukiman, dan lokasi lahan yang masih produktif. Indonesia telah memiliki standarisasi dalam memilih lokasi TPA.

Terdapat beberpa penelitian terkait penentuan lokasi Tempat Pembuangan Akhir. Pada penelitian yang dilakukan oleh Renista et al., (2015) yaitu penentuan lokasi TPA dengan system landfill di Tulang Bawang Barat, provinsi Lampung. Penentuan sanitary landfill yang dilakukan meliputi jumlah populasi, 
kondisi topografi, jarak dengan jalan, area banjir, menghitung volume sampah per hari berdasarkan unit dan satuan berat (kg) dan mengkaji kondisi sosial ekonomi wilayah penelitian. Hasil penelitian menghasilkan proyeksi jumlah penduduk pada tahun 2033 dengan jumlah 330.087 orang dengan jumlah volume sampah yang dihasilkan $1237.43 \mathrm{~m}^{3}$ /hari dan kebutuhan lahan untuk TPA dengan sanitary landfill di Kecamatan Tulang Bawang Barat selama 20 tahun adalah 17,70 Ha. Pada penelitian (Reinita, 2018) penentuan lokasi TPA di Kabupaten Sumedang menggunakan metode eksploratif dengan menggunakan data primer yang diperoleh dari data lapangan dan data sekunder yaitu diperoleh dari instansi-intansi terkait, yaitu diantaranya data curah hujan, data peta geologi. Dalam penelitian yang dilakukan analisis skoring dan pembobotan mengacu pada SNI 03-3241:1994 dengan hasil kesimpulan kesesuaian lokasi TPA sampah di Sumedang dibagi menjadi 3 kategori yaitu 1 kategori kelas tidak sesuai dan 2 kategori wilayah sesuai berdasarkan analisis skoring dan pembobotan yang dilakukan. Penelitian (Irawan \& Yudono, 2014) mengenai penentuan TPAS di Pulau Bintan, Riau menggunakan analisis system informasi geografis dari hasil yang didapatkan dari penelitian tersebut belum terdapat hasil satu lokasi alternatif TPAS. Peneliti dalam hal ini mengkaji penentuan lokasi TPA yang spesifik dengan menggunakan pendekatan analisis Sistem Informasi Geografis (SIG) dan mengacu pada SNI 033241:1994 serta melakukan analisis dengan validasi lapangan untuk mengetahui kesesuaian hasil analisis SIG dengan kondisi di lapangan sehingga didapatkan hasil yang sudah tervalidasi sebagai rekomendasi pemerintah kota Bandar Lampung.

Tujuan dari penelitian ini adalah untuk menentukan dan memilih lahan alternatif TPA sampah di Kota Bandar Lampung dengan memenuhi aspek-aspek yang mengacu dalam standar SNI dengan menganalisis secara spasial menggunakan Sistem Informasi Geografis. Penelitian ini diharapkan dapat menjadi rujukan pemerintah Kota Bandar Lampung dalam menentukan lokasi alternatif TPA Bakung sebagai upaya dalam mengurangi volume sampah dan dampak lingkungan yang ada.

\section{METODE PENELITIAN}

Prosedur penelitian ini merupakan tahap pengolahan data mengenai hal yang terkait dengan penelitian yang dilakukan dengan sistematis dimulai dari pengumpulan data sehingga diperoleh hasil. Diagram alir ditunjukkan pada Gambar 1.

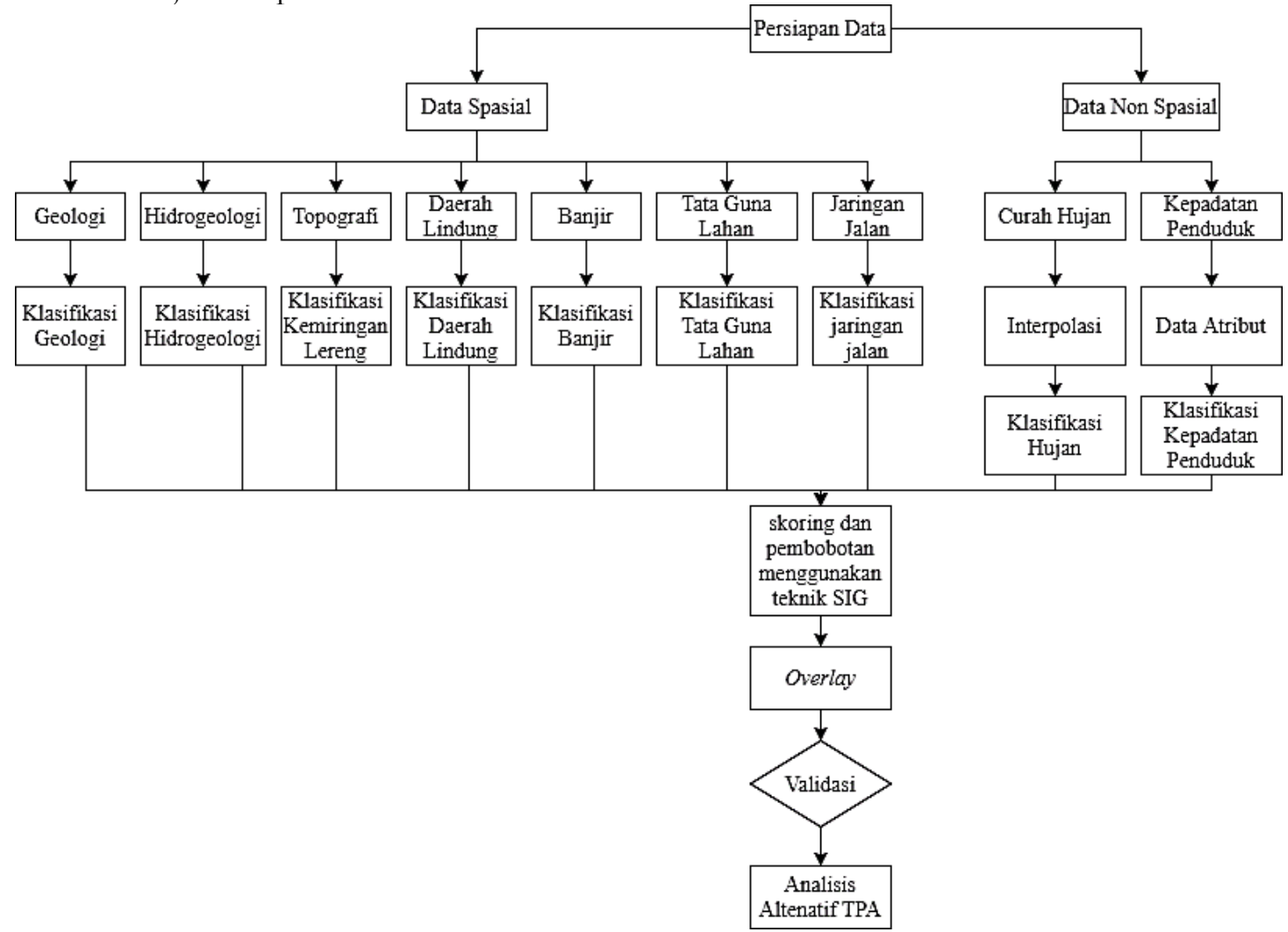

Gambar 1. Prosedur Penelitian

(Sumber: Peneliti, 2020) 
Penelitian ini menggunakan data spasial yang terdiri dari data geologi, hidrogeologi, topografi, daerah lindung, banjir, tata guna lahan. Sedangkan data non spasial terdiri dari data curah hujan, dan data kepadatan penduduk. Dalam menentukan kelayakan lokasi TPA Sampah perlu dilakukan analisis, maka analisis yang dilakukan adalah metode skoring. Penentuan skor masing-masing variabel didasarkan atas pembobotan parameter-parameter dari masing-masing variabel tersebut. Besarnya bobot dari masing-masing parameter ditentukan atas dasar besarnya pengaruh kepentingannya. metode skoring melalui pembobotan dan penilaian terhadap parameter dan indikator-indikator yang mempengaruhi kelayakan TPA sampah berdasarkan hasil kajian terhadap kritria pemilihan lokasi TPA sampah. Pemberian nilai bobot disini dimaksudkan untuk menghindari subyektivitas penilaian. Sedangkan bobot itu sendiri berarti peringkat kepentingan dari setiap parameter (Khadiyanto, 2005). Selanjutnya dilakukan interpretasi melalui analisis kualitatif dan menyimpulkan temuan yang didapat dari hasil analisis.

Teknik analisis data yang digunakan dalam penelitian ini menggunakan teknik analisis SIG yang mengacu pada SNI 03-3241-1994 sebagai berikut:

1) Kondisi Geologi

Data geologi dimanfaatkan untuk penentuan parameter zona holocene fault atau daerah sesar yang masih aktif dan zona bahaya geologi seperti bahaya longsor. Lokasi dengan tingkat bahaya gempa dan bahaya longsor yang tinggi tidak disarankan untuk dijadikan lokasi Tempat Pembuangan Akhir (TPA) sampah.

2) Kondisi Hidrogeologi

Data hidrogeologi dimanfaatkan untuk menganalisis parameter berupa lokasi mata air dan ketersediaan air tanah. Keberadaan suatu TPA dapat mempengaruhi kualitas sumber mata air dan ketersedian air tanah di suatu daerah untuk kepentingan pengadaan air bersih bagi daerah dan sekitarnya. Oleh sebab itu lokasi TPA harus tidak berada di daerah dengan ketersediaan air tanah yang tinggi dan jarak TPA ke sumber mata air harus lebih dari 100 meter. Tabel 1 merupakan kelas dan kriteria hidrogeologi.

Tabel 1. Kelas dan Kriteria Kondisi Hidrogeologi

\begin{tabular}{cll}
\hline Kelas & & \multicolumn{1}{c}{ Kriteria } \\
\hline \multirow{2}{*}{ Sesuai } & - Tidak boleh mempunyai muka air tanah kurang dari 3 meter \\
& - Tidak boleh kelulusan tanah lebih besar dari 10-6 cm/detik \\
& - Jarak terhadap sumber air minum harus lebih besar dari 600 meter di hilir aliran \\
& - Mempunyai muka air tanah kurang dari 3 meter \\
Tidak Sesuai & - Kelulusan tanah lebih besar dari 10-6 cm/detik \\
& - Jarak terhadap sumber air minum harus kurang dari 600 meter di hilir aliran
\end{tabular}

3) Topografi

Data kondisi topografi digunakan untuk menganalisis kemiringan lereng untuk mengetahui kondisi yang sesuai dalam analisis alternatif TPA yang dapat dilihat pada Tabel 2.

Tabel 2. Kelas dan Kriteria Topografi

\begin{tabular}{cl}
\hline Kelas & \multicolumn{1}{c}{ Kriteria } \\
\hline Sesuai & Kemiringan zona harus kurang dari 15\% \\
Tidak Sesuai & Kemiringan zona lebih dari 15\% \\
\hline
\end{tabular}

4) Data Hutan Lindung

Daerah lindung merupakan kawasan konservasi yang dikelola oleh pemerintah pusat. Perkembangan wilayah konservasi dibiarkan secara alami dengan menjadikan wilayah konservasi sebagai kawasan alami yang dilindungi sehingga tidak dapat dijadikan kawasan TPA sampah dan kegiatan komersil lainnya yang ditunjukkan pada Tabel 3 . 
Tabe1 3. Kelas dan Kriteria Hutan Lindung

\begin{tabular}{cl}
\hline Kelas & \multicolumn{1}{c}{ Kriteria } \\
\hline Sesuai & Tidak boleh pada daerah lindung \\
Tidak Sesuai & Berada pada daerah lindung \\
\hline
\end{tabular}

5) Data bencana banjir

Kerawanan banjir adalah keadaan yang menggambarkan mudah atau tidaknya suatu daerah terkena banjir dengan didasarkan pada faktor-faktor alam yang mempengaruhi banjir. Data daerah rawan banjir diperlukan untuk mengetahui lokasi yang terdampak banjir tahunan atau musiman sehingga tidak terjadi pencemaran air limbah pada lokasi alternatif TPA. Tabel 4 merupakan kelas dan kriteria bencana banjir.

Tabel 4. Kelas dan Kriteria Bencana Banjir

\begin{tabular}{cc}
\hline Kelas & Kriteria \\
\hline Sesuai & Tidak boleh pada lokasi yang terjadi bencana banjir dengan periode ulang 25 tahun \\
Tidak Sesuai & Bencana banjir dengan periode 25 tahun \\
\hline
\end{tabular}

Skoring dilakukan untuk pemberian skor terhadap setiap masing-masing parameter. Pada tahap pembobotan untuk mengetahui pengaruh setiap parameter dilakukan pembobotan sesuai dengan besarnya nilai skoring setiap parameter dalam kajian penelitian. Kedua metode tersebut berpengaruh terhadap klasifikasi setiap parameter. Skoring dan pembobotan dilakukan pada tahap penyisih dimana tahap ini merupakan tahapan untuk menghasilkan lokasi terbaik diantara beberapa lokasi yang dipilih dari zona kelayakan tahap tahap regional. Parameter dan bobot dari penilaian tersebut dapat dilihat dalam Tabel 5.

Tabel 5. Parameter Pembobotan Penentuan TPA

\begin{tabular}{|c|c|c|c|c|}
\hline No. & Parameter & & Nilai & Bobot \\
\hline \multirow[t]{8}{*}{$\mathbf{I}$} & UMUM & & & \\
\hline & Batas Administrasi & & 5 & \\
\hline & & dalam batas administrasi & & 10 \\
\hline & & di luar batas administrasi tetapi & & \\
\hline & & $\begin{array}{l}\text { dalam satu sistem pengelolaan } \\
\text { TPA sampah terpadu }\end{array}$ & & 5 \\
\hline & & di luar batas administrasi dan & & \\
\hline & & $\begin{array}{l}\text { diluar pengelolaan TPA sampah } \\
\text { terpadu }\end{array}$ & & 1 \\
\hline & & di luar batas administrasi & & 1 \\
\hline \multirow[t]{9}{*}{ II } & \multicolumn{2}{|c|}{ LINGKUNGAN FISIK } & & \\
\hline & $\begin{array}{l}\text { Tanah (di atas muka } \\
\text { air tanah) }\end{array}$ & & 5 & \\
\hline & & harga kelulusan $<10^{-9} \mathrm{~cm} /$ det & & 10 \\
\hline & & $\begin{array}{l}\text { harga kelulusan } 10^{-9} \mathrm{~cm} / \text { det - } \\
10^{-6} \mathrm{~cm} / \text { det }\end{array}$ & & 7 \\
\hline & & harga kelulusan $>10^{-6} \mathrm{~cm} /$ det & & \\
\hline & & $\begin{array}{l}\text { Tolak (kecuali ada masukan } \\
\text { teknologi) }\end{array}$ & & \\
\hline & Bahaya banjir & & 2 & \\
\hline & & tidak ada bahaya banjir & & 10 \\
\hline & & $\begin{array}{l}\text { kemungkinan banjir }>25 \\
\text { tahunan }\end{array}$ & & 5 \\
\hline \multirow[t]{3}{*}{ III } & Lingkungan Fisik & & & \\
\hline & & kemungkinan banjir $<25$ & & \\
\hline & & $\begin{array}{l}\text { tahunan Tolak (kecuali ada } \\
\text { masukan teknologi) }\end{array}$ & & 1 \\
\hline \multirow[t]{2}{*}{3.} & Tanah penutup & & 4 & \\
\hline & & tanah penutup cukup & & 10 \\
\hline
\end{tabular}


4. Intensitas hujan

5. Jalan menuju lokasi

6. Transpot sampah (satu jalan)

7. Lalu lintas

IV

8. Tata guna lahan

9. Daerah lindung/cagar alam

10. Kebisingan dan bau tanah penutup cukup sampai $1 / 2$ umur pakai

tanah penutup tidak ada

di bawah $500 \mathrm{~mm}$ per tahun antara $500 \mathrm{~mm}$ sampai $1000 \mathrm{~mm}$ per tahun

di atas $1000 \mathrm{~mm}$ per tahun

datar dengan kondisi baik

datar dengan kondisi buruk naik/turun

$$
\begin{aligned}
& \text { kurang dari } 15 \text { menit dari } \\
& \text { centroid sampah } \\
& \text { antara } 16 \text { menit - } 30 \text { menit dari } \\
& \text { centroid sampah } \\
& \text { antara } 31 \text { menit - } 60 \text { menit dari } \\
& \text { centroid sampah } \\
& \text { lebih dari } 60 \text { menit dari centroid } \\
& \text { sampah } \\
& \text { terletak } 500 \mathrm{~m} \text { dari jalan umum } \\
& \text { terletak }<500 \mathrm{~m} \text { pada lalu lintas } \\
& \text { rendah } \\
& \text { terletak }<500 \mathrm{~m} \text { pada lalu lintas } \\
& \text { sedang } \\
& \text { terletak pada lalu lintas tinggi }
\end{aligned}
$$
terletak $500 \mathrm{~m}$ dari jalan umum terletak $<500 \mathrm{~m}$ pada lalu lintas rendah
terletak $<500 \mathrm{~m}$ pada lalu lintas sedang
mempunyai dampak sedikit terhadap tata guna tanah sekitar mempunyai dampak sedang terhadap tata guna tanah sekitar mempunyai dampak besar terhadap tata guna tanah sekitar

tidak ada daerah lindung/cagar alam di sekitarnya

terdapat daerah lindung/cagar alam di sekitarnya yang tidak terkena dampak negatif terdapat daerah lindung/cagar alam di sekitarnya terkena dampak negatif
terdapat zona penyangga
terdapat zona penyangga yang terbatas tidak terdapat penyangga

3

5

Sumber : Badan Standarisasi Nasional, 1994.

Validasi merupakan proses pengecekan lokasi setelah pengolahan data selesai dilakukan dan didapatkan lokasi yang sesuai. validasi lapangan yang dilakukan menggunakan metode random sampling. Dimana pengambilan sampel dilakukan secara acak atau random. Dalam Simple Random Sampling atau biasa disingkat Random Sampling merupakan suatu cara pengambilan sampel dimana tiap anggota populasi diberikan opportunity (kesempatan) yang sama untuk terpilih menjadi sampel (Arieska \& Herdiani, 2018). Dalam penelitian ini penentuan titik sample dilakukan pada wilayah sesuai dan sangat 
sesuai berdasarkan hasil overlay yang telah dilakukan pada tahap regional dan tahap penyisih dengan persamaan (BIG, 2014) berikut:

$$
\text { Jumlah Sampel }=\mathrm{TSM}+\frac{\operatorname{Luas}(\mathrm{ha})}{1500}
$$

Dengan TSM adalah jumlah sampel minimal yang dibutuhkan dalam penentuan titik validasi berdasarkan Tabel 2 .

Tabel 6. Penentuan Titik Sampel

\begin{tabular}{ccc}
\hline No. & Skala & Total Sampel Minimal (TSM) \\
\hline 1. & $1: 25.000$ & 50 \\
2. & $1: 50.000$ & 30 \\
3. & $1: 250.000$ & 20 \\
\hline
\end{tabular}

Sumber : Badan Informasi Geospasial, 2014.

\section{TEMUAN DAN PEMBAHASAN}

Tahapan analisis regional merupakan tahapan untuk mendapatkan informasi lokasi layak dan tidak layak untuk TPA sampah. Beberapa indikator yang digunakan untuk menentukan tingkat kesesuaian lokasi TPAS pada tahap regional ini antara lain kondisi geologi, kondisi hirogeologi, kemiringan lereng, jarak terhadap lapangan terbang, dan daerah lindung/cagar alam dan bahaya banjir (Malikah et al., 2020). Parameter-parameter yang digunakan dalam analisis regional ini sesuai dengan SNI nomor 19-3241-1994 yang diterbitkan oleh Badan Standarisasi Nasional. Hasil dari tahap regional diklasifikasikan menjadi tiga kelas berdasarkan data dan parameter yang telah dilakukan overlay yaitu warna hijau merupakan kelas yang sangat sesuai, warna kuning merupakan kelas sesuai dan warna merah merupakan kelas tidak sesuai yang ditunjukkan pada Gambar 2.

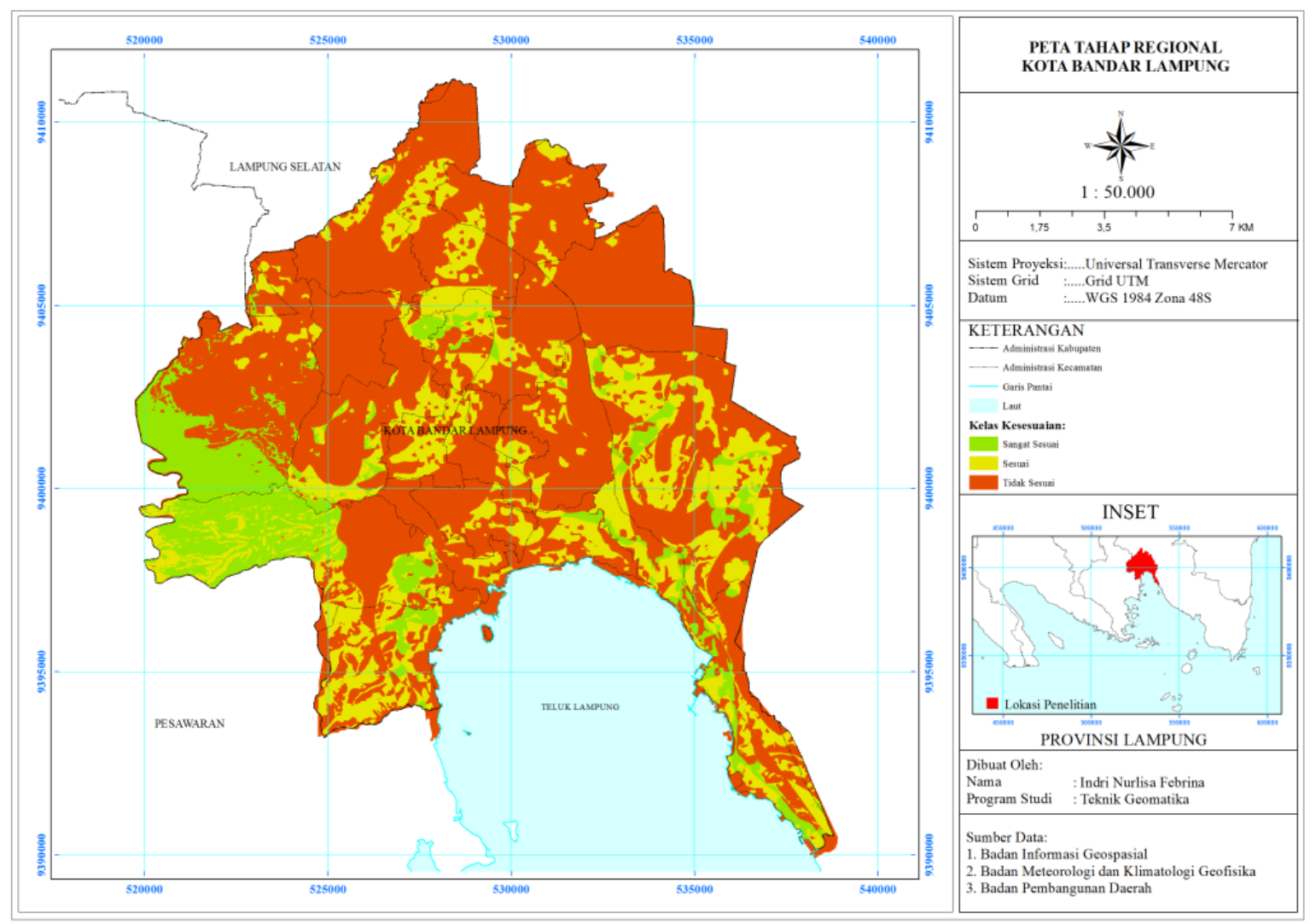

Gambar 2. Peta Hasil Tahap Regional (Sumber: Peneliti, 2020) 
Selanjutnya dilakukan tahap penyisih yang merupakan tahapan untuk menghasilkan satu atau dua lokasi terbaik diantara beberapa lokasi yang dipilih dari zona-zona kelayakan pada tahap regional. Parameter pada tahap kriteria tahap penyisih diperoleh melalui tahap regional yang dilakukan skoring dan pembobotan meliputi parameter curah hujan, utilitas, lingkungan biologis, kondisi tanah, demografi, bau, estetika dan kebisingan. Pada tahap penyisih dilihat transport sampah untuk mendapatkan rute terdekat dari centroid sampah pasar menuju calon lokasi TPA. Hasil Alternatif TPA sampah terdapat 2 lokasi alternatif pada wilayah Kecamatan Teluk Betung Barat dan Kecamatan Kemiling dengan total luas sebesar 477.48 Hektar yang ditunjukkan pada Gambar 3.

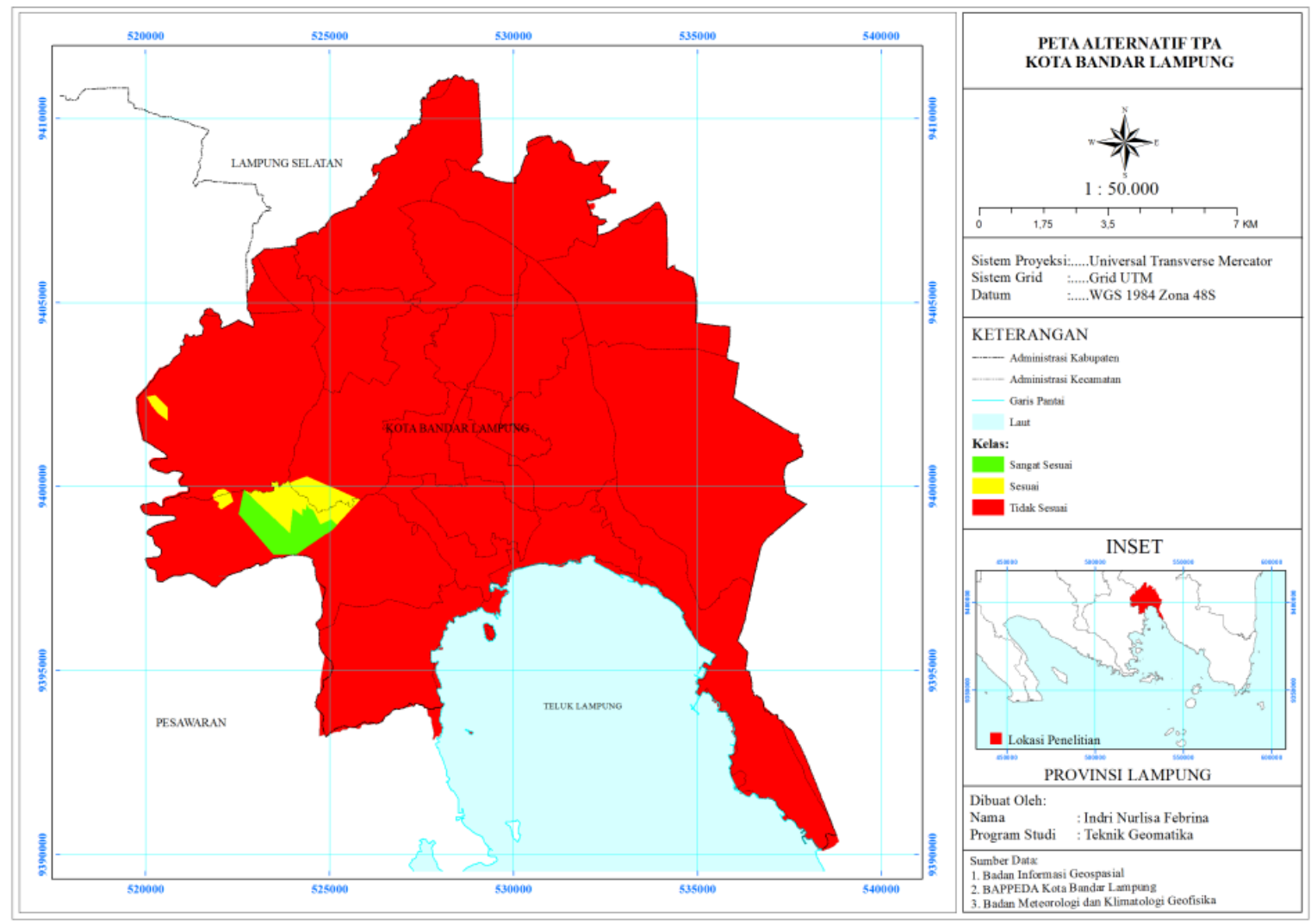

Gambar 3. Peta Hasil Tahap Penyisih

(Sumber: Peneliti, 2020)

Validasi lapangan dilakukan dengan metode random sampling yaitu mengambil titik sampel secara acak pada wilayah yang sesuai dalam tahap overlay pada tahap penyisih yang menunjukkan kesesuaian berdasarkan skoring dan pembobotan dengan luasan wilayah yang sesuai yaitu 477.48 Hektar sehingga validasi yang dilakukan dengan 34 titik sampel untuk memverifikasi data hasil overlay. Validasi yang dilakukan berada di wilayah Teluk Betung Barat, berdasarkan validasi yang telah dilakukan diketahui bahwa terdapat wilayah yang sesuai dan tidak sesuai ditinjau dari kemiringan lereng yang kurang dari $20 \%$, aksesibilatas jalan yang baik dan jauh dari pemukiman penduduk serta mempertimbangkan luasan area TPA yang akan dijadikan alternatif dengan luasan minimal 20 Hektar. Gambar 4 menunjukkan sebaran titik validasi lapangan.

Berdasarkan Peraturan Daerah Provinsi Lampung Nomor 1 Tahun 2010 Tentang Rencana Tata Ruang Wilayah (RTRW) Provinsi Lampung (2009-2029) sistem pengelolaan harus terpadu dan sistematis sehingga menerapkan konsep sanitary landfill dalam menentukan lokasi alternatif sesuai standar pengelolaan sampah di Indonesia untuk mengurangi dampak bagi lingkungan dan manusia. Hasil validasi yang telah dilakukan lahan yang dapat dijadikan lokasi alternatif TPA sampah sesuai hasil validasi dengan total luas sebesar 42,17 Hektar terdapat 3 wilayah yang berlokasi di Kecamatan Teluk Betung Barat dengan luas wilayah pertama 32 Hektar, wilayah kedua dengan luas 6.6 Hektar dan wilayah ketiga 3.56 Hektar yang ditunjukkan pada Gambar 5. 


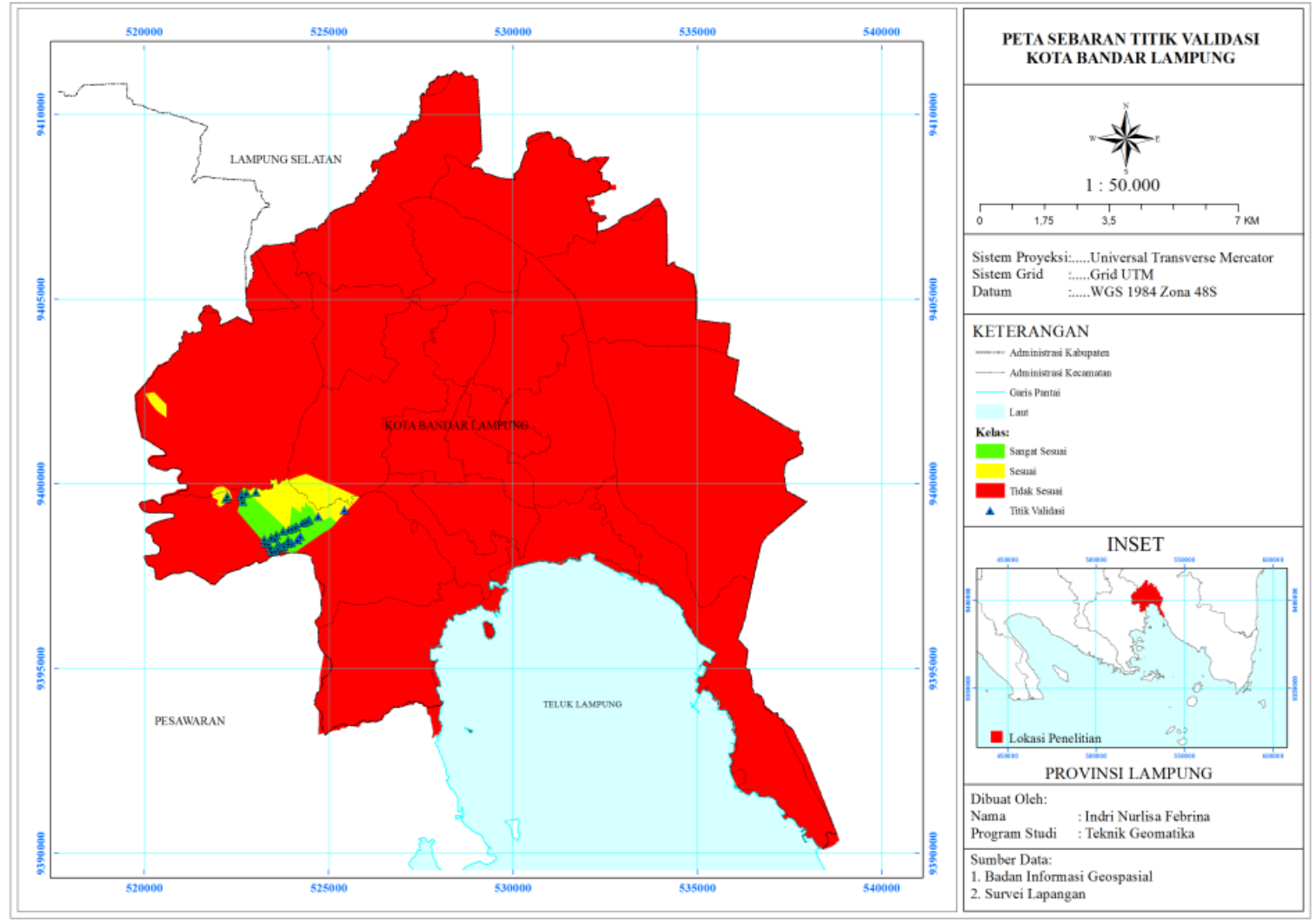

Gambar 4. Peta Sebaran Titik Validasi (Sumber: Peneliti, 2020)

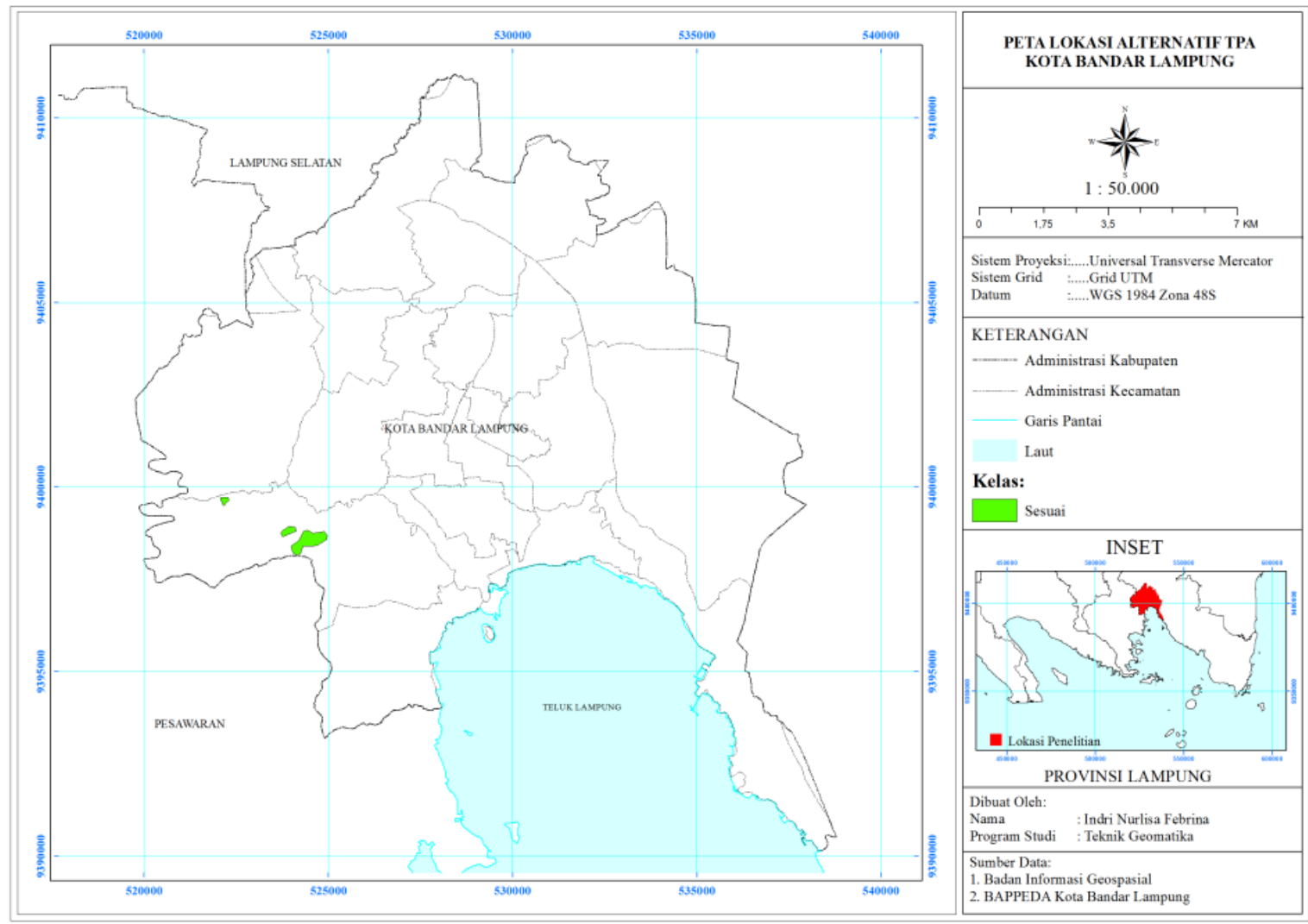

Gambar 5. Peta Alternatif TPA berdasarkan Validasi Lapangan (Sumber: Peneliti, 2020) 


\section{SIMPULAN}

Berdasarkan hasil temuan dan pembahasan diketahui bahwa Lahan dengan kelas sesuai untuk lokasi alternatif TPA sampah Kota Bandar Lampung terdapat di wilayah Kecamatan Teluk Betung Barat dan Kecamatan Kemiling dengan total luasan sebesar 477.48 Hektar. Dari hasil validasi yang dilakukan dapat disimpulkan bahwa lahan yang dapat dijadikan lokasi alternatif TPA sampah sesuai hasil validasi di lapangan yaitu sebesar 42.17 Hektar yang terbagi pada 3 wilayah yang berlokasi di Kecamatan Teluk Betung Barat dengan luas wilayah pertama 32 Hektar, wilayah kedua dengan luas 6.6 Hektar dan wilayah ketiga 3.56 Hektar.

\section{DAFTAR PUSTAKA}

Akbar, R. (2016). Analisa Kelayakan Lokasi Tempat Pembuangan Akhir Sampah Kelurahan Gampong Jawa, Banda Aceh Menggunakan Sistem Informasi Geografis. ETD Unsyiah.

Apritama, M. R., Oktiawan, W., \& Wardhana, I. W. (2016). Studi Pemilihan Lokasi Tpa Regional Bregasmalang (Brebes, Tegal, Slawi, Pemalang). Jurnal Teknik Lingkungan, 5(2), 1-8.

Arieska, P. K., \& Herdiani, N. (2018). Pemilihan Teknik Sampling Berdasarkan Perhitungan Efisiensi Relatif. Jurnal Statistika Universitas Mubammadiyah Semarang, 6(2), 166-171.

Badan Standarisasi Nasional. (1994). SNI 03-3241-1994 Tentang Tata Cara Pemilihan Lokasi TPA Sampah. Jakarta: Badan Standarisasi Nasional.

BIG (2014). Peraturan Kepala Badan Informasi Geospasial Nomor 3 Tahun 2014; Tentang Pedoman Teknis Pengumpulan dan Pengolahan Data Geospasial Mangrove.

Chandra, B. (2006). Pengantar Kesehatan Lingkungan. Jakarta: Penerbit Buku Kedokteran.

Fauzi, A. (2016). Pemanfaatan sistem informasi geografis (SIG) untuk analisis kelayakan perluasan tempat pembuangan akhir (TPA) sampah Cipeucang Kota Tangerang Selatan.

Hendra Y. (2016). Perbandingan Sistem Pengelolaan Sampah di Indonesia dan Korea Selatan: Kajian 5 Aspek Pengelolaan Sampah. Journal Aspirasi,7(1), 77-91.

Irawan, A. B., \& Yudono, A. R. A. (2014). Studi Kelayakan Penentuan Tempat Pemrosesan Akhir Sampah (TPA) di Pulau Bintan Propinsi Kepulauan Riau. Jurnal Ilmu Lingkungan, 12(1), 1-11.

Iriani, L. G. (2013). Aplikasi Penginderaan Jauh dan SIG Untuk Evaluasi Kesesuaian Lahan Lokasi TPA Sampah Menggunakan Model Builder di Kecamatan Nanggulan, Kabupaten Kulonprogo, Yogyakarta. Yogyakarta: Fakultas Geografi Universitas Gadjah Mada.

Kasam, I. (2011). Analisis Resiko Lingkungan pada Tempat Pembuangan Akhir (TPA) Sampah (Studi Kasus: TPA Piyungan Bantul). Jurnal Sains \& Teknologi Lingkungan, 3(1), 19-30.

Kesuma, R. (2011). Kajian Terhadap Pengelolaan Sampah di Kota Bandar Lampung.

Khadiyanto, P. (2005). Tata Ruang Berbasis Pada Kesesuaian Laban. Semarang: Universitas Diponegoro.

Mahyudin, R. P. (2017). Kajian Permasalahan Pengelolaan Sampah dan Dampak Lingkungan di TPA (Tempat Pemrosesan Akhir). Jukung (Jurnal Teknik Lingkungan),3(1), 66-74.

Malikah, S., Widiyanti, B. L., Apriyeni, B. A. R., \& Hadi, H. (2020). Analisis Sistem Informasi Geografis Untuk Penentuan Lokasi Tempat Pemrosesan Akhir Sampah di Kabupaten Lombok Timur. Geodika: Jurnal Kajian Ilmu dan Pendidikan Geografi, 4(2), 172-181.

Manik, K. E. S., \& Eddy, K. (2003). Pengelolaan Lingkungan Hidup. Jakarta (ID): Djambatan. Minerals, and Sustainable Development, (183).

Phelia, A., \& Damanhuri, E. (2019). Kajian Evaluasi Tpa Dan Analisis Biaya Manfaat Sistem Pengelolaan Sampah Di Tpa (Studi Kasus TPA Bakung Kota Bandar Lampung) Evaluation Of Landfill And Cost Benefit Analysis Waste Management System Landfill. 
Pirngadi, B.H. (2013). Studi Penentuan Lokasi TPA Regional Provinsi Baanten (Wilayah Pelayanan Tanggerang Raya). Tidak dipublikasikan.

Rahman, M. H., \& Al-Muyeed, A. (2010). Solid and Hazardous Waste Management. Dhaka: ITN-BUET Centre for Water Supply and Waste Management.

Reinita, N. (2018). Penentuan Lokasi Tempat Pembuangan Akhir Sampah Di Kabupaten Sumedang Dengan Bantuan Sisitem Informasi Geografis. Skripsi. Bandung: Universitas Pendidikan Indonesia.

Renisita, D., Sunjoto, S., \& Sarto, S. (2015). The Determination of Landfill (TPA) Alternative Location In West Tulang Bawang District Of Lampung Province. Asean Journal of Systems Engineering, 3(1), $11-17$.

Sari, A. M. N. (2014). Isolasi dan Karakterisasi Bakteri Pendegradasi Plastik Hitam dari TPA (Tempat Pembuangan Akhir) Sampah Bakung Kota Bandar Lampung dengan Teknik Konvensional.

Undang-undang Republik Indonesia Nomor 18 Tahun 2008 tentang Pengelolaan Sampah. 